\title{
Is Storytelling Effective in Improving the English Vocabulary Learning among Iranian Children in Kindergartens?
}

\author{
Maasumeh Abasi \\ Department of English Language and Literature Larestan Branch, \\ Islamic Azad University, Larestan, Iran \\ E-mail: maasumehabasi@Yahoo.com \\ Afshin Soori \\ Department of English Language and Literature Larestan Branch, \\ Islamic Azad University, Larestan, Iran \\ E-mail: afshin_soori@yahoo.com
}

Received: 09-05- 2013

Accepted: 07-06-2013

Published: $30-07-2014$

doi:10.7575/aiac.ijels.v.2n.3p.7

URL: http://dx.doi.org/10.7575/aiac.ijels.v.2n.3p.7

\begin{abstract}
The aim of this study is to investigate the effectiveness of storytelling in improving English vocabulary learning among children in kindergarten. Twenty Iranian children (9 boys and 11 girls) in a private kindergarten in Kerman, Iran, were the participants of the study. All of the children were five years old and were taught English with the same teacher in a class in a kindergarten. The design of the study was one group pre-test post-test quasi experimental design. Both pre and post-tests included 20 vocabulary picture items taken from a story book teaching in the kindergarten. The statistical analysis revealed that storytelling was effective in increasing vocabulary learning among kindergarten children.
\end{abstract}

Keywords: vocabulary learning, storytelling, kindergarten, children

\section{Introduction}

Stories are considered as an important part of everyday lives like the food we eat and water we drink. "Stories help us to understand who we are, to make sense of the confusing swirl of everyday life, to digest and transform our experiences. They can also serve to develop reflection and critical thinking." (Booth, 1994, p.89). Stories can make our world. Life is full of stories, and the life stories include different characters, places and 'events. In fact, stories can provide the human beings with helpful knowledge, and experience and they can make the life meaningful. To Booth (1994), stories can form a fundamental way for organizing the human experience. Thus, a way to look back in time is storytelling "to move forward and it is an active process" (Booth, 1994 as cited in Mokhtar, et al., 2011 p. 164). By telling and listening to stories, people can share experience, values and ideas. "The way our minds think is the essence of the story. Therefore, to communicate effectively, it is important to engage people, break down barriers and ensure that they remember facts" (Mokhtar, et al., 2011 p. 164).

Storytelling is considered as an ancient verbal art which is defined in different ways. To Gere (2002) storytelling is "the act of using language and gesture in colorful ways to create scenes in a sequence" (cited in Behmer, 2005, p. 2). McDrury and Alterio believe that storytellinge is a unique capability which is able to convey human experience through language of words. Regarding these definitions, sharing some ideas and experiences through words and actions to communicate is the general characteristic of storytelling (Behmer, 2005).

When the word 'storytelling' is heard, we often think of children. Since stories are rich materials for children, they are able to learn more about the world they live through stories. Every situation in real life can be tangible "in the magical world of story. In fact, whatever children learn in the story world can be practical in the real world" (Soleimani \& Akbari, 2013, p.4005). Stories can make some suitable situations for children to get some necessary experiences about the problems and dangers of their future life. Thus, they are able to cope with future problems.

Children from different ages love stories. From early childhood, the children are told stories of different natures. They like to listen to fairly tales in which "the never-ending struggle of powers of good and evil takes place Stories of their childhood, stories of our own childhood, stories talking about fun accidents or happy memories, stories describing exciting and amusing situations appertain to children's most favorite ones" (Hronova, 2011, p.15). Wright (2008) believes that stories play important roles in the lives of children. In fact, stories can help children to know the world around them better. "Driven by the need to understand and to live with the complexity of daily experience, children hunger for stories" (Wright, 2008 as cited in Hronova, 2011, p. 15). An storybook can be an ideal means for children to learn a foreign language. Stories "can also served as the starting-point for other related language and learning activities" (Ellis, et al., 1991, as cited in Hronova, 2011, p. 15). 
Georgiou and Verdugo (2010) refer to different reasons for providing storytelling to young learners. In a meaningful context, storytelling can combine listening, speaking, reading and writing. Georgiou and Verdugo (2010) believe that in a meaningful context, grammar, vocabulary and speech that can support comprehension are presented through stories. Storytelling "fosters cultural awareness and offers values and beliefs. It stimulates children's curiosity and encourages them to learn more about the world" (Georgiou \& Verdugo, 2010 as cited in Soleimani \& Akbari, 2013, p.4005 ). To Wasik and Bond (2001), stories can make language comprehensible and memorable. Gibbons (2002) believes that stories are suitable scaffolding tools which can help learning process. In addition, learners can progress gradually in their own construction and reconstruction of knowledge (Georgiou \& Dolores, 2010 as cited in Soleimani \& Akbari, 2013, p.4005).

When the learners retell or remember the plot of the story, the story can help them to foster cognitive and social skills. " $[\mathrm{C}]$ cognitive activities such as identifying characters, comparing their behaviors and reactions during story and defining concepts, lead to develop concrete thinking, and cognitive activities such as: reasoning, finding solution, and creative ending lead to develop abstract thinking" (Soleimani \& Akbari, 2013, p.4005). To Dolakova (2008) a fluent stream is provided by the story which makes the children listen better and help them to produce or reproduce it. It seems that children are able to understand the stories even if they do not know the meaning of any word that has been used in the story. "Since they [children] can use the predictive power of the text which help them to guess the meaning; they also use the gesture, the posture, and the intonation of storyteller to process and understand the meaning (Dolakova, 2008, as cited in Soleimani \& Akbari, 2013, p.4005).

According to Dolakova (2008), stories are known based on their contents as "classical tales, animal tales or fables, repetitive and cumulative tales, adventures and romantic stories, poem, rhymes, songs and chants" (cited in Dolakova, 2008, p.267). Dolakova (2008) also stated that classical tales are the most common types of tales for children of different cultures. In this case, the children are familiar with the plot, characters and can guess the ending of these types of stories. Thus, they are able to guess the meaning of the unknown words. However, these types of stories have some problems like the length of the stories and the large number of the words which avoid teachers from using them in the classroom.

Since children like animals, these types of stories are the most popular tales among the children. Children mostly like the characters of these stories which are animals and these animals because talk and think like human beings. Children like to imitate the behaviors and actions of the characters in these stories (Dolakova, 2008).

According to Dolakova (2008), some types of tales like repetitive and cumulative tales are very suitable for learning language because their plots are short and they contain repetitive rhythms which can assist children remember the plot of the stories and also enable them to reproduce words and structures in a very short time. In addition, these stories include some comprehensive answers for children's repetitive questions which make the teacher or parents exhausted.

Other types of stories which are popular among children are adventurous and romantic stories, because they contain some hero and heroine characters that are attractive for the children. Moreover, they include some bad characters that are bad, ugly and nasty. Children like these types of stories because they always have happy endings and they can see the overcoming of good or positive characters over bad or negative ones. Dolakova (2008) believes that Cinderella is the most familiar adventurous and romantic story for the children. Dolakova (2008, as cited in Soleimani \& Akbari, 2013, p.4006) also states that "Poems, rhymes, songs and chants are also great sources for listening because of the repetitive nature of rhymes, their plot and their imaginative nature; they can foster the motivation and language ability of children."

\section{Review of Related Literature}

A powerful and effective way to increase the level of vocabulary acquisition in an EFL context is storytelling Maldelez (2010). Motivation and interest of the students will be developed by the use of storytelling method (Moon \& Maeng, 2012). Gonzalez (2010) identified that some stories which are used for children in language centers to teach a foreign language can motivate and increase their participation for conducting different activities in the classroom. There are numerous studies on the effect of storytelling on learning a second language. Isbell, et al. (2004) explored the impact of storytelling on increasing the reading comprehension among young learners. The outcome of their study revealed that storytelling was effective for improving the comprehension skills among the children. They concluded that the children who listened to the stories had greater reading comprehension than those children who just read the stories. To Cameron (2001), storytelling is a kind of oral activity that has been designed for both listening and involvement, and it can make children participate in class activities. He asserts that eye contact between the teacher and the children can play an essential role in storytelling because eye contact is a kind of behavior which is natural in communication, and it can increase the communication ability among the students in the classroom. To Baker and Greene (1985, as cited in Lenox, 2000, p. 1) "telling a story is giving a gift . . . storytelling brings to the listener heightened awareness - a sense of wonder, of mystery, of reverence for life". They also refer to storytelling as a "gift of understanding of self and others, and understanding the story itself" (Baker and Greene1977, as cited in Soleimani \& Akbari, 2013, p.4006). Some researchers (e.g. Kaderavek \& justice, 2002; Rubin \& Wilson, 1995; Snow, 1983) believe that reading story books by teachers in the classroom is a very suitable activity which is recommended in educational literature, and it is beneficial for children's language learning. According to Alna (1999), except the entertainment value of storytelling, it may have some value as an educational tool and the role of storytelling has been highlighted for many teachers and scholars. Farrell and Nessel (1982) believe that storytelling is very useful in the reading classroom. 
Storytelling is almost always used in nearly all nursery schools and kindergartens in Iran. In fact, it is a kind of tradition among Iranian families. Most children are familiar with "lots of archetypes, plot structures, different types of characters and themes, and they also know a large amount of fables and anecdotes which they inherited from their ancestors" (Soleimani \& Akbari, 2013, p.4006). Despite the familiarities of children with these stories, unfortunately they are not comprehensively used in language classes for children (Soleimani \& Akbari, 2013). Vocabulary plays an important role in learning a second or foreign language. However, the children are taught vocabulary based on rote learning method. Teachers mostly ask the children to repeat or memorize a large number of words. Or, they ask the children to match words with the pictures. Children learn these words through their pictures, out of text. Total Physical Response (TPR) is another method of teaching vocabulary in Iran, and by using this method, teachers teach action verbs. (Soleimani \& Akbari, 2013). Teachers also use some songs for teaching vocabulary for kindergarten students. However, it is not a meaningful method of learning vocabulary. As the children do not know the meaning of the words, they just repeat the words without understanding their meanings. Regarding this issue, the researcher of the current study is going to investigate the effectiveness of storytelling on vocabulary learning among the children in a kindergarten. To this end, the research question is as follows: Is storytelling effective in improving the vocabulary learning among the children in a kindergarten?

\section{Methodology}

\subsection{Participants}

The participants of the present study were 20 children (9 boys and 11 girls) in a private kindergarten in Kerman Iran. The average age of the participants was five. These children were taught with the same English textbook and they had the same English teacher.

\subsection{Instruments}

In the current study an English storybook was chosen to teach the participants in the kindergarten. The textbook that was taught was Three Bears. In addition, the researcher made a vocabulary test to be administered as pre and post-tests. In order to motivate the children, they were given some stickers as gifts.

\subsection{Procedure}

The researcher prepared a vocabulary test from their storybook. The vocabulary test included both known and unknown vocabulary. Known words were those that were taught in the kindergarten, and unknown words were those words in the storybook which were new and unfamiliar for the children. In this stage, the researcher asked their English teacher about the vocabulary knowledge of the children in the class and also was consulted about the more familiar and less familiar items for children. The vocabulary test was a multiple choice test with pictures. Since the children were not able to read or write, the teacher read the words for them and they ticked the correct answers. To this end, the teacher read the words and the children ticked the answers on answer sheets which had been prepared in advance.

Then, the English teacher taught the storybook in three stages: pre-storytelling, during-storytelling, and post-storytelling stages. Pre-storytelling stage continued for 3 sessions, each lasted one hour. The main aim of pre-storytelling was to prepare the children for better comprehending of the story. Therefore, they were motivated to listen and follow the story. Then, the teacher tried to introduce the new words by the help of some flashcards and asked children to draw some pictures of new words.

The second stage was during-storytelling stage, which lasted 3 sessions; each session lasted one hour. During the first session of this stage, the teacher read half of the story for children, and they were shown some pictures. Then, the teacher asked them some questions based on the pictures. The teacher kept on reading the rest of the story to keep them motivated and active. Post-storytelling was the last stage which lasted two sessions "which was the generalization of the new knowledge to the student's real life" (Soleimani \& Akbari, 2013, p. 4007). In this stage, the teacher asked children some questions about their lives. Finally, the teacher administered the post test. The teacher read the new words and the children ticked their answers.

\section{Results}

Table 1 indicates the descriptive statistics of the pretest. In this Table, the Skewness value is -.347 and the Standard Error of Skewness is .411. As shown in this Table, the Skewness value is less than the two times value of Standard Error of Skewness.

Table1. Descriptive statistics for the Pretest

\begin{tabular}{llllllllllll}
\hline Mean & $\begin{array}{l}\text { Std. } \\
\text { Error of } \\
\text { Mean }\end{array}$ & Median & Mode & $\begin{array}{l}\text { Std. } \\
\text { Deviation }\end{array}$ & variance & Skewness & $\begin{array}{l}\text { Std. Error } \\
\text { Skewness }\end{array}$ & of & Range & Max. & Min. \\
& & & & & & & & & & & \\
\hline 19.30 & .654 & 18.00 & 18 & 2.79 & 14.465 & -.347 & .411 & 14 & 15 & 29 \\
\hline
\end{tabular}

Table 2 shows the descriptive statistics of the posttest. In this table, the Skewness value is -.460 and the Standard Error of Skewness .379. As illustrated inTable 2, the Skewness value is less than the standard error of skewness. 
Table2. Descriptive statistics for the Posttest

\begin{tabular}{llllllllllll}
\hline Mean & $\begin{array}{l}\text { Std. } \\
\text { Error of } \\
\text { Mean }\end{array}$ & Median & Mode & $\begin{array}{l}\text { Std. } \\
\text { Deviation }\end{array}$ & variance & Skewness & $\begin{array}{l}\text { Std. Error } \\
\text { Skewness }\end{array}$ & of & Range & Max. & Min. \\
\hline 23.40 & .537 & 23.00 & 22 & 3.36 & 11.748 & -.465 & .411 & 13 & 18 & 31 \\
\hline
\end{tabular}

As shown in table3, one sample kolmogorov-smirnove test was done. Asymp. Sig.(2 tailed) reveals that both pretest and post test are more than the p. value 0.05 . Thus, the results show the existence of a normal distribution.

Table3. One-Sample Kolmogorov-Smirnov Test

\begin{tabular}{lllc}
\hline & & pretest & posttest \\
$\mathrm{N}$ & & 20 & 20 \\
Normal parameters & Mean & 19.30 & 23.40 \\
Most extreme differences & Std. deviation & 2.79 & 3.36 \\
& Absolute & .142 & .128 \\
& Positive & .094 & .082 \\
& Negative & -.142 & -.128 \\
Kolmogorov-Smirnov Z & & .854 & .649 \\
Asymp. Sig. (2-tailed) & & .326 & .673 \\
\hline
\end{tabular}

\section{Discussion}

The statistical data obtained from the vocabulary test indicates that storytelling is an effective way to improve the abilities of vocabulary learning for children in kindergartens. As it was mentioned earlier, there was one group of fiveyear-old children and a vocabulary test was administered as pre and post-test. Then, the results of pre and post-test were compared. The results revealed that the children in the post-test performed better in the vocabulary test. Moreover, in comparison to the pre-test, the mean of the group in the post-test showed a significant increase. This indicates that storytelling is effective in improving the children's vocabulary learning.

The findings of the current study was in line with the earlier study by Ab Rashid (2012) which reported that storytelling was effective in increasing vocabulary learning of less proficient young adults. Mohamad Rafik (2005) was another researcher in the area of storytelling who investigated the effects of storytelling on the elementary students. He found that storytelling was effective for the elementary students. Joyce (2011) investigated the impacts of song picture books on the vocabulary acquisition among the children in kindergarten. He found that song picture books had a positive effect on increasing the vocabulary acquisition of students in kindergarten.

Although the researcher tried her best to eliminate the limitations, there were inevitably a few minor limitations while conducting this study. Thus, these limitations should be taken into account when further research is designed. One limitation was the sample size which was small with 20 children in a kindergarten. Thus, a larger group of children in kindergarten or preschool may have a different result. Another limitation is related to the duration of the study which was limited to six sessions a longer duration of instruction may have provided different results.

\section{Conclusion}

The statistical analysis indicated that storytelling can be a helpful method for children and it increases vocabulary learning. Since there are not adequate studies related to the effectiveness of story and storytelling, story books are not used widely in kindergarten, preschools and nursery schools in Iran. However, the results of the current study allow the teachers or course designers to see the potential and effectiveness of storytelling in increasing the vocabulary learning among the children in kindergartens and preschools. In addition, the outcomes of this study reveal that storytelling enables children to learn the vocabulary in context. However, further studies are required to be conducted to investigate how to best use of children's stories to improve learning a second or foreign languages among children in kindergartens and preschools.

\section{References}

Abrashid R. (2012). Vocabulary learning among less proficient young adults using children's Stories. Mextesol Journal,35(1).

Baker, R., \& Greene, M. (1985). Storytelling: Art and Technique. London: Lonman.

Booth, D. (1994). Story Drama. Canada: Pembroke Publishers Limited. 
Cameron, Lynne (2001): Teaching Languages to Young Learners. Cambridge: Cambridge Language Teaching Library.

Dolokova S. (2008). Storytime activities in primary classes and kindergartens (Master thesis) . Masary University of Brono, Faculty of Education.

Ellis, G. \& Brewster, J. (1991). The storytelling handbook for primary teachers. Penguin

Georgious S, Dolores R. (2010). Stories as a tool for teaching and learning in CLIL, (pp.137-155), Nicosia Cyprus Pedagogical Institute.

Hronova. K. (2011). Using Digital Storytelling in the English Language Classroom. Unpublished Bachelor Thesis.

Isbell, R., Sobol, J., Lindauer, L, \& Lowrance, A. (2004). The Effects of Storytelling and Story Reading on the Oral Language Complexity and Story Comprehension of Young Children. Early Childhood Education Journal 32, 157-163.

Joyce M. (2011). Vocabulary acquisition with kindergarten children using song picture book (Doctoral dissertation), Norttheastern University, Boston, Massachusetts.

Lenox M. (2000). Storytelling for young children in a multicultural world. Early childhood Educational journal, 28(2).

Mohamad Rafik F. (2005). Storytelling and vocabulary acquisition at the elementary level (Master thesis). Mentouri University, Contantin Faculty of Letters and Languages, Democratic and Popular Republic of Algeria.

Mokhtar, Nor Hasni, Abdul Halim, M.F, Zurina, S. (2011). The Effectiveness of Storytelling in Enhancing Communicative Skills. Procedia Social and Behavioral Sciences 18,163-169.

Moon J, \& Maeng U. (2012). A comparison study of the effect of reading instruction using storytelling and storysinging. Proceeding of 17th conference of Pan-Pacific Association of Applied Linguistic. School of Education, Ajou University.

Soleimani, H. \& Akbari, M. (2013). The Effect of Storytelling on Children's Learning English Vocabulary: A Case in Iran. International Research Journal of Applied and Basic Sciences, 4 (11), pp. 4005-4014.

Wright, A. (2008).Storytelling with children. Oxford: Oxford University Press. 